\title{
Kajian Biblika Tentang Dosa Yang Tidak Mendatangkan Maut Berdasarkan Surat 1 Yohanes 5:1-21 dan Implikasinya Bagi Orang Kristen
}

\author{
Geo Frayanus, Armin Sukri
}

\begin{abstract}
Abstrak
Tujuan penulisan skripsi ini ialah untuk menjelaskan pertama, makna dosa yang tidak mendatangkan maut menurut surat 1 Yohanes 5:16-17. Kedua, untuk menjelaskan apa implikasi dosa yang tidak mendatangkan maut bagi orang percaya berdasarkan surat 1 Yohanes 5:16-17. Adapun metode penulisan yang digunakan penulis ialah metode kualitatif, yaitu dengan mencari makna dari dosa yang tidak mendatangkan maut dalam surat 1 Yohanes 5:1-21 dengan menggunakan pendekatan hermeneutik untuk meneliti Alkitab sebagai sumber utama, dengan mengunakan analisis teks, analisis konteks dengan mencari makna dari setiap kata-kata penting dalam nas atau memakai analisis leksikal.

Dari hasil penelitian ini maka penulis menarik beberapa kesimpulan: pertama, dosa yang tidak mendatangkan maut adalah suatu perbuatan dosa yang tidak menyebabkan kehilangan hidup kekal dan ini terjadi kepada orang yang percaya kepada Yesus. Kedua, makna dosa yang tidak mendatangkan maut adalah perbuatan dosa yang dapat diampuni atau dosa yang mendapatkan pengampunan dari Allah. Ketiga, adanya perbuatan dosa yang tidak mendatangkan maut, tidak sekalipun dikehendaki Allah untuk dengan sengaja atau sadar untuk melakukan dosa tersebut. Keempat, sikap orang percaya ialah hidup dalam pertobatan dan membenci dosa, serta tidak mengulangi kesalahan yang sama dan diperhamba oleh dosa. Kelima, bersyukur untuk anugerah pengampunan yang Allah berikan dan terus hidup dalam kebenaran Kristus.
\end{abstract}

Kata-kata Kunci: Dosa, Hidup Kekal, Pengampunan, Orang Percaya.

\section{Pendahuluan}

\section{Latar Belakang Masalah}

Surat Yohanes merupakan surat yang dimaksudkan untuk meyakinkan orang Kristen mengenai iman mereka dan untuk memperbaharui kepercayaan yang telah tergoncang oleh ajaran sesat yang berkembang saat itu. ${ }^{1}$ Adapun ajaran sesat yang berkembang saat itu adalah Gnostikisme, suatu ajaran filsafat yang menjadi ancaman terbesar bagi gereja hingga akhir abad yang kedua. ${ }^{2}$

\footnotetext{
${ }^{1}$ David Alexander, Pat Alexander, (ed.), Handbook To The Bible (Bandung: Kalam Hidup, 2015),
} 124.

\footnotetext{
${ }^{2}$ Merrill C. Tenney, Survei Perjanjian Baru (Malang: Gandum Mas, 2009), 462.
} 
Gnostikisme adalah suatu Filsafat agama bukan suatu sistem tersendiri. Ia dibangun berdasarkan anggapan bahwa roh adalah baik, dan tubuh adalah jahat, dan di antara keduanya tidak mungkin ada suatu hubungan yang kekal. Keselamatan berarti kebebasan dari dunia jasmani masuk ke dalam dunia rohani. Dan pertentangan antar filsafat ini dengan agama Kristen adalah yang menyangkut pribadi Kristus. Bagaimana mungkin roh yang begitu agung dan suci yang disebut Allah dapat dihubungkan dengan suatu tubuh jasmani? ${ }^{3}$

Selain Gnostikisme terdapat juga ajaran-ajaran sesat lainnya yang berkembang dan mempengaruhi iman orang Kristen. Ajaran-ajaran tersebut mengutamakan kerohanian dan pengetahuan dari pada kehidupan moral, dan meyakini kelahiran kembali secara rohani. Hal itu membuat mereka tidak mungkin lagi berbuat dosa, karena itu, tidak ada dosa yang perlu diakui (1:9-10). ${ }^{4}$ Selain itu, ajaran yang menentang kebenaran yaitu antikristus (2:18-19) yang berasal dari kalangan orang-orang Kristen sendiri yang memutarbalikkan injil kebenaran dan menentang bahwa Yesus itu adalah Kristus $(2: 22) .{ }^{5}$ Adanya pengajaran yang menyimpang ini ditanggapi dengan serius oleh Yohanes, sehingga ia terdorong untuk menulis surat. Jemaat perlu disadarkan terhadap penyesatan yang berbahaya ini. ${ }^{6}$

Penulis Surat Yohanes mengangkat tema-tema penting untuk memberikan pengajaran yang sesuai dengan injil dan kebenaran yang didengar, dilihat dan disaksikan (1:1). Salah satu tema penting dan menarik adalah kehidupan orang Kristen yang masih hidup di dalam kegelapan dan dosa $(1: 6,8)$ yang walaupun sebenarnya terang dan kebenaran itu sudah ada dan siap menerangi kegelapan itu serta menyucikan segala dosa (1:5:7). Menurut Morris dalam buku Teologi Perjanjian Baru: "Dosa adalah pelanggaran hukum (3:4) dan dosa berarti menolak untuk taat kepada hukum Allah dan memaklumkan kehendak sendiri."7

Awal mula manusia mengalami keterpisahan dan hubungan yang rusak dengan Allah adalah karena dosa (Kejadian 3).

Hukum Perjanjian Lama tampak kejam bagi kita menurut standar masyarakat sekarang. Tetapi kita hidup dalam sebuah zaman di mana dosa yang serius tidak lagi dianggap serius. Dalam penciptaan, semua dosa terhadap Allah dianggap sebagai kesalahan yang sangat besar. Dalam tindakan pemberontakan yang sangat kecil kita melakukan penghianatan yang sangat besar. Dan setiap dosa terhadap Allah yang kudus dan benar dapat menimbulkan kematian. ${ }^{8}$

Meskipun dosa merupakan suatu pelanggaran yang begitu serius, tetapi masih ada orang yang masih mengabaikannya, termasuk oleh sebagian orang Kristen yang seringkali menganggap remeh soal perbuatan dosa (1 Yoh. 1:6; 2:1; 3:8-9). Saat dosa sudah masuk dan menjadi bagian dari manusia, dosa itu mendatangkan maut dan membawa kepada kebinasaan atau kematian kekal. Tertulis dalam Roma 6:23, Sebab upah dosa ialah maut; tetapi karunia

${ }^{3}$ Ibid.

${ }^{4}$ Howard Clark Kee, dkk., (ed.), Alkitab Edisi Studi (Jakarta: Lembaga Alkitab Indonesia, 2014), 2028.

${ }^{5}$ Donald C. Stamps, (ed.), Alkitab Penuntun Hidup Berkelimpahan (Malang: Gandum Mas, 1994), 2116.

${ }^{6}$ Donald Guthrie, Pengantar Perjanjian Baru Volume 3 (Surabaya: Momentum, 2014), 183.

${ }^{7}$ Leon Morris, Teologi Perjanjian Baru (Malang: Gandum Mas, 2014), 402.

${ }^{8}$ R. C. Sproul, Mengapa Percaya (Malang: Seminari Alkitab Asia Tenggara, 2013), 19. 
Allah ialah hidup yang kekal dalam Kristus Yesus Tuhan kita. Daniel Ronda menuliskan "dalam Perjanjian Baru sering kali istilah dosa dipakai dengan istilah hamartia, yang berarti tidak kena sasaran dan meliputi gagasan kegagalan, salah dan perbuatan jahat." 9

Sehingga suatu perbuatan yang menyimpang dan tidak sesuai dengan aturan atau hukum Allah merupakan pelanggaran. Pemahaman tentang tidak menjadi masalah untuk berbuat dosa merupakan pemahaman yang keliru, sebab dalam Roma 6:23 menyatakan bahwa semua upah dosa adalah maut, yang berarti bahwa sangat menjadi masalah apabila melakukan dosa.

Dalam Surat 1 Yohanes 5:16-17 dibedakan antara "dosa yang tidak mendatangkan maut" dan "dosa yang mendatangkan maut". Pembedaan ini sangat menarik, sebab bagaimana para pembaca dapat memahami, bahwa ada dosa yang tidak mendatangkan maut? Sepertinya bertolak belakang dengan pemahaman mengenai dosa seperti yang telah diuraikan sebelumnya, bahwa dosa adalah pelanggaran terhadap hukum Allah dan sesuatu yang mendatangkan maut dan pasti ada hukuman yang tegas dari perbuatan dosa yang dilakukan. Stephen Tong mengungkapkan,

Sejak dulu sampai sekarang kita melihat penjara tidak pernah mungkin dihapuskan dari masyarakat. Bukan saja demikian, kita malah melihat bahwa walaupun pertumbuhan teknologi dan kemajuan ilmu pengetahuan semakin populer, serta pendidikan semakin merata, namun tidak mengurangi keberadaan dari penjara-penjara. Ini membuktikan bahwa dosa adalah unsur kedua yang tidak pernah berubah. ${ }^{10}$

Dalam buku Tafsiran Alkitab Abad 21, penafsir tidak secara gamblang menjelaskan apa itu dosa yang tidak mendatangkan maut, tetapi lebih mengarah kepada dosa yang mendatangkan maut dengan mengatakan:

Seharusnya kita memandang dosa yang mendatangkan maut sebagai suatu keadaan bukan perbuatan, di dalam Alkitab tidak ada satu perbuatan khusus yang dilakukan orang yang mendatangkan maut, tetapi ada keadaan berdosa, keadaan memberontak melawan Allah, contohnya dosa menghujat Roh Kudus. ${ }^{11}$

Penafsir memberikan cukup penjelasan mengenai apa itu dosa yang mendatangkan maut, tetapi tidak menjelaskan mengenai dosa yang tidak mendatangkan maut, padahal dalam 1 Yohanes 5:16-17, dibedakan antara keduanya. Adanya dosa yang tidak mendatangkan maut dapat menjadi alasan bagi orang percaya untuk dapat berbuat dosa. Seolah-olah dengan melakukannya tidak menjadi masalah, sebab hanya dosa yang mendatangkan maut yang dianggap lebih serius, sedangkan dosa yang tidak mendatangkan maut tidak dianggap sebagai suatu ancaman ketika melakukannya.

Perbuatan-perbuatan apa saja yang dikategorikan sebagai dosa yang tidak mendatangkan maut juga masih kabur dan tidak jelas. Dalam buku Tafsiran Alkitab Perjanjian Baru juga tidak diungkapkan mengenai hal ini. Sepertinya para penafsir lebih banyak mengarah kepada dosa yang mendatangkan maut saja, sebagaimana diungkapkan dalam Tafsiran Alkitab Perjanjian Baru bahwa:

${ }^{9}$ Daniel Ronda, Dasar Teologi Yang Teguh: Panduan Teologi Sistematika Di Perguruan Tinggi (Makassar: Sekolah Tinggi Theologia Jaffray, 2013), 81.

${ }^{10}$ Stephen Tong, Dosa, Keadilan, Penghakiman (Surabaya: Momentum, 2006), 4.

${ }^{11}$ D. A. Carson, R. T. France, J. A. Motyer, G. J. Wenham, Tafsiran Alkitab Abad Ke-21 MatiusWahyu (Jakarta: Yayasan Komunikasi Bina Kasih, 2017), 704. 
Beberapa penafsir mengemukakan bahwa yang dimaksudkan dengan dosa yang mendatangkan maut adalah pembunuhan dan perzinahan. Tetapi, tampaknya yang lebih sesuai dengan seluruh 1 Yohanes, dosa itu menunjuk masalah murtad secara sadar, lebih memilih kegelapan dari pada kehidupan, kebencian dari pada kasih. ${ }^{12}$

Tentunya menjadi pertanyaan besar bagi setiap pembaca surat 1 Yohanes 5:16-17, dikarenakan tidak adanya cukup informasi yang memberikan pemahaman atau perbuatan apa saja yang dikatakan dosa yang tidak mendatangkan maut itu. Apabila memang tidak dijelaskan, mengapa penulis surat membedakan antara dosa yang mendatangkan maut dan tidak mendatangkan maut ini. Karena secara umum orang Kristen memahami bahwa setiap perbuatan dosa pasti mendatangkan maut, Alkitab sendiri yang mengatakan itu dalam (1 Kor. 15:56; Yak. 1:15; Rom. 6:23) bahwa upah dari dosa itu adalah maut dan kuasa dosa itu maut. Bahkan dalam surat 1 Yohanes 5:17a mengatakan semua kejahatan adalah dosa yang menyatakan bahwa semua perbuatan yang jahat dan melanggar adalah dosa. Oleh sebab itu pernyataan penulis surat 1 Yohanes dalam pasal 5:16-17 seolah-olah dalam bahasa seharihari dimengerti ada dosa tertentu yang dapat dilakukan sebab itu tidak mendatangkan suatu malapetaka dalam kehidupan orang tersebut atau dapat diartikan secara harfiah ada dosadosa tertentu yang tidak membuat diri kita dihukum atau menjadi bersalah ketika melakukannya.

Dosa merupakan sesuatu yang serius dan Allah adalah Pribadi yang sangat membenci dosa. Namun, jika ada pemahaman yang salah tentang ungkapan Yohanes, bahwa "ada dosa yang tidak mendatangkan maut", maka tentu ini akan menjadi polemik yang serius. Stephen Tong menuliskan,

Kalau menghukum dosa lebih daripada seharusnya, berarti yang dihukum tidak mendapatkan keadilan, yang menghukum juga tidak mendapatkan keadilan. Jikalau hukuman tidak mencapai seharusnya, atau lebih dari seharusnya dihukum, berarti dia juga tidak mendapat keadilan yang seharusnya. Itulah sebabnya keadilan menjadi suatu standar untuk menilai moral dan etika seseorang. ${ }^{13}$

Demikian pendapat Jerry mengenai dosa dalam buku Respectable Sins,

Dosa adalah tumor ganas spiritual dan moral. Jika dibiarkan, dosa dapat menyebar ke seluruh keberadaan batin kita dan mencemari setiap bagian hidup kita. Bahkan lebih buruk lagi, dosa seringkali akan "menjalar" dari kita ke dalam orang-orang percaya lain di sekeliling kita. Dan dosa adalah sebuah prinsip atau kekuatan moral di dalam hati kita, keberadaan batin kita. Sehingga kegagalan untuk menyadari realitas yang mengerikan dari kebenaran inilah yang menyediakan lahan yang subur untuk bertumbuhnya dan berkembangnya dosa-dosa kita yang "diangap pantas" atau " dapat diterima". ${ }^{14}$

12 Dianne Bergant, CSA, Robert J. Karris, OFM, Tafsiran Alkitab Perjanjian Baru (Yogyakarta: Kanisius, 2002), 465.

${ }^{13}$ Stephen Tong, Dosa, Keadilan, Penghakiman (Surabaya: Momentum, 2006), 5.

${ }^{14}$ Jerry Bridges, Respectable Sins: Dosa-Dosa Yang Dianggap Pantas (Bandung: Pionir Jaya, 2008), 25-27. 
Tanpa ada ganjaran yang jelas, maka dosa hanyalah menjadi penyakit atau masalah yang biasa-biasa saja, sebab masih ada banyak orang yang tidak menanggap dosa dan konsekuensinya sebagai satu hal yang serius. Padahal Yesus sendiri dalam pelayanan-Nya walaupun mencari orang berdosa (Mat. 9:13; Mrk. 2:17), Yesus sendiri tidak suka terhadap dosa bahkan mengajarkan jauh lebih dalam lagi tentang perbuatan dosa (Mat. 5:27-30) dan harus hidup dalam kebenaran. Hal inilah yang menjadi alasan bagi penulis untuk menyelidiki maksud Yohanes tentang "dosa yang tidak mendatangkan maut" berdasarkan I Yohanes 5:16-17. Apa saja dosa yang tidak mendatangkan maut itu? Apakah benar ada dosa yang tidak mendatangkan maut?

\section{Pokok Masalah}

Berdasarkan latar belakang tersebut, maka masalah pokok yang akan dibahas dalam penulisan skripsi ini adalah:

Pertama, apa makna dosa yang tidak mendatangkan maut menurut surat 1 Yohanes 5:16-17?

Kedua, apa implikasi dosa yang tidak mendatangkan maut berdasarkan surat 1 Yohanes 5:16-17 bagi orang percaya?

\section{Tujuan Penelitian}

Pertama, untuk menemukan makna dosa yang tidak mendatangkan maut menurut surat 1 Yohanes 5:16-17

Kedua, menemukan implikasi dosa yang tidak mendatangkan maut berdasarkan surat 1 Yohanes 5:16-17

\section{Manfaat Penelitian}

Dalam penulisan skripsi ini, penulis mempunyai pengharapan yang diwujudkan sebagai manfaat dari penulisan, yaitu:

Pertama, untuk memahami dan mengerti makna dosa yang tidak mendatangkan maut.

Kedua, untuk mengerti implikasi yang baik serta praktis dari dosa yang tidak mendatangkan maut.

Ketiga, untuk menjadi bahan bacaan yang dapat menambah wawasan bagi para pembaca.

Keempat, untuk memenuhi salah satu persyaratan dalam menyelesaikan program Stratum Satu (S1) di Sekolah Tinggi Theologia Jaffray Makassar.

\section{Metode Penelitian}

Adapun metode penulisan yang dipakai dalam skripsi ini ialah metode kualitatif, yaitu metode penelitian kepustakaan (Library Research), terhadap berbagai sumber di antaranya: Alkitab, kamus-kamus, buku-buku tafsiran surat 1 Yohanes serta buku-buku yang berkaitan dengan judul dalam penulisan skripsi ini. Dalam pembahasan penulis juga menggunakan prinsip atau metode hermeneutik

\section{Batasan Penelitian}

Dalam penelitian ini penulis hanya berfokus pada makna dosa yang tidak mendatangkan maut berdasarkan surat 1 Yohanes 5:16-17 dan implikasinya bagi orang percaya. 


\section{Kesimpulan}

Penulis 1 Yohanes menyatakan bahwa bukan hanya ada dosa yang mendatangkan maut, melainkan yang lebih menarik lagi bahwa ada dosa yang tidak mendatangkan maut. Dari seluruh uraian yang sudah penulis uraikan, khususnya tentang dosa yang tidak mendatangkan maut, maknanya, serta implikasinya bagi orang percaya berdasarkan 1 Yohanes 5:16-17, penulis menyimpulkan bahwa:

Pertama, yang dimaksudkan dengan dosa yang tidak mendatangkan maut merupakan perbuatan dosa yang tidak menyebabkan kehilangan kehidupan kekal dan ini terjadi kepada orang yang percaya. Perbuatan dosa itu apa saja, yaitu yang di luar semua perbuatan dosa yang mendatangkan maut, yaitu menolak untuk tidak percaya dan mengakui Yesus Kristus sebagai Anak Allah. Salah satu wujud nyatanya penolakkan itu ialah dengan menyembah berhala, sebab Allah yang benar itu telah diganti dengan ilah-ilah palsu lainnya. Dengan mengetahui dan memahami apa itu dosa yang tidak mendatangkan maut, bukan berarti harus atau dengan sengaja ingin melakukannya, melainkan harus wajib hidup seperti Kristus dan hidup dalam kebenaran (1 Yoh. 2:6). Dosa yang tidak mendatangkan maut adalah dosa yang dapat diampuni atau dosa yang mendapat pengampunan dari Allah.

Kedua, untuk perbuatan dosa yang tidak mendatangkan maut selalu ada pengampunan dari Allah karena Yesus Kristus, sehingga setiap orang yang percaya atau pun jemaat Tuhan yang merasa bahwa dosanya tidak diampuni merupakan pemahaman yang keliru, Dengan demikian yang benar ialah, Allah mengampuni segala pelanggaran dan perbuatan-perbuatan dosa yang dilakukan, dan menyucikan semua dosa itu karena darah-Nya dan nama-Nya (1 Yoh. 1:9; 2:12 bnd. Kol. 2:13-15).

Ketiga, setiap orang yang percaya yang tahu dan memahami bahwa ada dosa yang tidak mendatangkan maut, tidak sekalipun dikehendaki Allah untuk dengan sengaja atau sadar untuk berbuat dosa tersebut. Melainkan dengan senantiasa hidup dalam kebenaran menjauhi segala kejahatan dan dosa, serta segala berhala yang akan membuat orang percaya nantinya tidak mengenal Allah yang benar. Sehingga sikap orang yang percaya kepada Yesus Kristus, ialah hidup dalam pertobatan dan membenci dosa serta tidak lagi mengulangi kesalahan yang sama dengan cara, tidak membuka celah sedikit pun untuk membiarkan diri untuk berbuat dosa atau pun memperhamba diri dengan dosa (Gal. 5:16-26 bnd. Gal. 6:7; Ibr. 6:4-6). Selain dari pada itu, saat jatuh dalam dosa, cepat berbalik dan mengambil sikap untuk bertobat dan memohon pengampunan kepada Allah. Sebab Allah menghendaki setiap orang yang percaya bertobat dan menjauhi berhala dalam kehidupannya.

Keempat, sebagai orang percaya yang hidup dalam kasih karunia Allah, tidak menghakimi saudara seimannya apabila berbuat dosa yang tidak mendatangkan maut, melainkan senantiasa membawa dia ke dalam doa (Yak. 5:19-20). Inilah wujud nyata dari mengasihi sesama itu, bukan menghakimi, apa lagi saudara seiman yang berbuat dosa yang tidak mendatangkan maut, selain membutuhkan teguran kasih, yang paling mudah dan sederhana untuk dilakukan namun berdampak besar ialah dengan mendoakannya (Gal. 6:1$10)$.

Kelima, setiap orang yang percaya harus mengerti kasih karunia dan pengampunan yang Allah berikan. Itulah sebabnya perbuatan dosa yang tidak mendatangkan maut tidak boleh terlepas dari iman seseorang kepada Kristus. Hanya anugerah Allah dan di dalam Kristus saja setiap orang yang percaya beroleh kasih karunia dan penyelamatan, sehingga hidup kekal itu tetap berada di dalam kehidupan orang percaya. Oleh karena itu setiap orang 
yang percaya tidak boleh takut bahkan cemas akan kehilangan kehidupan yang kekal, dan tidak menerima pengampunan, melainkan selalu bersyukur untuk anugerah pengampunan yang diberikan dan terus hidup dalam kebenaran Kristus (1 Tes. 5:18).

\section{Kepustakaan}

Alexander, David, Pat Alexander (ed.). Handbook To The Bible. Bandung: Kalam Hidup, 2015.

Barclay, William. Pemahaman Alkitab Setiap Hari Surat-Surat Yohanes dan Yudas. Jakarta: BPK Gunung Mulia, 2011.

Bergant, Dianne, Robert J. Karris. Tafsiran Alkitab Perjanjian Baru. Yogyakarta: Kanisius, 2002.

Bridges, Jerry. Respectable Sins: Dosa-Dosa Yang Dianggap Pantas. Bandung: Pionir Jaya, 2008.

Busthan, Paskalinus. Materi Kuliah Teologi Perjanjian Baru. Makassar: Program Pascasarjana Sekolah Tinggi Theologia Jaffray, 2018. Belum dipublikasikan.

Carson, D. A., Douglas J. Moo. An Introduction To The New Testament. Malang: Gandum Mas, 2016.

Carson, D. A, R. T. France, J. A. Motyer, G. J. Wenham. Tafsiran Alkitab Abad Ke-21 3 Matius-Wahyu. Jakarta: Yayasan Komunikasi Bina Kasih, 2017.

Gaebelein, Frank E. The Expositor's Bible Commentary Volume 12 Hebrews-Revelation. Michigan: Regency Reference Library, 1981.

Gering, Howard M. Analisa Alkitab. Jakarta: Yayasan Pengkabaran Injil 'Imanuel', 1992.

Guthrie, Donald, et al (ed.). Tafsiran Alkitab Masa Kini Matius-Wahyu. Jakarta: BPK Gunung Mulia, 1983.

Guthrie, Donald. Pengantar Perjanjian Baru Volume 3. Surabaya: Momentum, 2014.

Henry, Matthew. Surat Ibrani, Yakobus, 1\&2 Petrus, 1-3 Yohanes, Yudas, Kitab Wahyu. Surabaya: Momentum, 2016.

Johnston, Philip. IVP Introduction To The Bible. Bandung: Yayasan Kalam Hidup, 2011.

Ladd, George Eldon. Teologi Perjanjan Baru Jilid 2. Bandung: Yayasan Kalam Hidup, 1999.

Mangis, Michael. Dosa Ciri Diri Menjinakkan Kecenderungan Liar Hati Kita. Jakarta: WASKITA Publishing, 2011.

Marshall, Howard, The New International Commentary On The New Testament The Epistles Of John. Grand Rapids: William B. Eerdmans Publishing Company, 1981.

Morris, Leon. Teologi Perjanjian Baru. Malang: Gandum Mas, 2014.

Pfeiffer, Charles F, Everett F. Harrison (ed.). Tafsiran Alkitab Wycliffe. Malang: Gandum Mas, 2013.

Piper, John. The Passion of Jesus Christ, Penderitaan Yesus Kristus. Surabaya: Momentum, 2013.

Ronda, Daniel. Dasar Teologi Yang Teguh: Panduan Teologi Sistematika Di Perguruan Tinggi. Makassar: Sekolah Tinggi Theologia Jaffray, 2013.

Rumahlatu, Jerry. Hermeneutik Sepanjang Masa. Jakarta: Cipta Varia Sarana, 2011.

Sproul, R. C. Mengapa Percaya. Malang: Seminari Alkitab Asia Tenggara, 2013.

Suawa, Ferdinan K. Memahami Gramatika Dasar Bahasa Yunani Koine. Bandung: Kalam Hidup, 2009. 
Sutanto, Hasan. Hermeneutik: Prinsip dan Metode Penafsiran Alkitab. Malang: Literatur SAAT, 2007. . Perjanjian Baru Interlinear Yunani-Indonesia dan Konkordansi Perjanjian Baru Jilid I PBIK. Jakarta: Lembaga Alkitab Indonesia, 2014. Perjanjian Baru Interlinear Yunani-Indonesia dan Konkordansi Perjanjian Baru Jilid II PBIK. Jakarta: Lembaga Alkitab Indonesia, 2014.

Tenney, Merrill C. Survei Perjanjian Baru. Malang: Gandum Mas, 2009. Tong, Stephen. Dosa, Keadilan, Penghakiman. Surabaya: Momentum, 2006.

Wenham, J. W. Bahasa Yunani Koine The Elements of New Testament Greek Malang: Seminari Alkitab Asia Tenggara, 1987.

Wijaya, Hengki. Analisis Data Kualitatif. Makassar: Sekolah Tinggi Theologia Jaffray, 2018. 